\title{
NOCTURNAL POLLINATION BY FUNGUS GNATS OF THE COLOMBIAN ENDEMIC SPECIES, PLEUROTHALLIS MARTHAE (ORCHIDACEAE: PLEUROTHALLIDINAE)
}

\author{
Carol Andrea Duque-Buitrago ${ }^{1}$, Néstor Fabio Alzate-Quintero ${ }^{1} \&$ J. Tupac Otero $^{2,3,4}$ \\ ${ }^{1}$ Departamento de Ciencias Biológicas, Facultad de Ciencias Exactas y Naturales, Herbario FAUC, \\ Universidad de Caldas, PO Box 275, Manizales, Colombia \\ ${ }^{2}$ Departamento de Ciencias Biológicas, Facultad de Ciencias Agropecuarias, Universidad Nacional de \\ Colombia, Sede Palmira \\ ${ }^{3}$ Instituto de Estudios Ambientales IDEA, Universidad Nacional de Colombia, Sede Palmira \\ ${ }^{4}$ Author for correspondence: jtoteroo@unal.edu.co
}

\begin{abstract}
Contemporary patterns of plant biodiversity result from the ecological and evolutionary processes generated by species interactions. Understanding these interactions is key for effective biodiversity conservation at the species and the ecosystem level. Orchid species often have highly specialised pollinator interactions, and the preservation of these is critical for in situ orchid conservation. The majority of orchid species occur in tropical regions, and information regarding their interactions is limited. We present data on pollinator identities, pollination mechanisms and flowering phenology of the Colombian endemic orchid, Pleurothallis marthae. We evaluated the mechanisms of attraction, the presence of osmophores, and the reproductive system of the species. Pleurothallis marthae is self-compatible with nocturnal anthesis pollinated by Mycetophila sp. (Mycetophilidae), probably attracted by a string fungus like smell liberated by the flower and Bradysia sp. (Sciaridae) that feed on nectar in the labellum. Osmophores and nectaries were detected in the epidermis of the sepals and petals. We present new evidence that the genus Pleurothallis is adapted to Diptera pollination. Our study indicates that the pollination mechanism of $P$. marthae is based on the nocturnal attraction of two species of fungus gnats, probably combining food attraction and brood place deception.
\end{abstract}

RESUMEN. Los patrones contemporáneos de biodiversidad vegetal son el resultado de procesos ecológicos y evolutivos generados por la interacción entre especies. El entendimiento de estas interacciones es clave para la conservación de la biodiversidad a nivel de especies y ecosistemas. A menudo las orquídeas tienen interacciones de polinización altamente especializadas, y su preservación es crucial para la conservación de orquídeas in situ. La mayoría de las especies de orquídeas ocurren en regiones tropicales, y la información sobre sus polinizadores es limitada. Aquí presentamos datos sobre la identidad de polinizadores, mecanismos de polinización y fenología floral de la orquídea Pleurothallis marthae, endémica de Colombia. Evaluamos los mecanismos de atracción, la presencia de osmóforos, y su sistema reproductivo. Encontramos que se trata de una especie auto-compatible con antesis nocturna polinizada por Mycetophila sp. (Mycetophilidae), especie atraída probablemente por el olor a hongo que libera la orquídea y Bradysia sp. (Sciaridae), la cual se alimenta de gotas de néctar en el labelo. Los osmóforos y nectarios fueron detectados en la epidermis de los sépalos y pétalos. El mecanismo de polinización de $P$. marthae se basa en la atracción nocturna de moscas especializadas en hongos, y combina atracción alimenticia y mimetismo de sitios de apareamiento.

KEY WORDS: Bradysia, orchid pollination, fungus gnats, pollinators, Mycetophila, olfactory mimicry

Introduction. As we are facing the sixth global biodiversity extinction (Canadell \& Noble 2001), the ultimate goal of plant conservation biology is to preserve an adequate environment in which species can persist (Swarts \& Dixon 2009), with continued evolutionary change. The effective conservation of individual species requires a deep taxonomic understanding (Flanagan et al. 2006), especially among those groups highly diversified such as Pleurothallidinae. It also demands the maintenance of species interactions in natural environments. One of the critical interactions for many plants is pollination by animals. It is also 
one of the interactions that have provided substantial evidence of evolutionary processes in the wild; revealing amazing adaptations associated with pollen transport (Darwin 1885). Nevertheless, pollination had been nominated as an endangered interaction due to losses of plant species and their pollinators as well as their natural habitats (Kearns et al. 1993). A flowering plant family that combines both, threat conservation in some species and interesting pollination interactions is the Orchidaceae.

Orchidaceae is the largest family of flowering plants with about 800 genera and more than 28,000 species (Govaerts et al. 2012); many species are endangered, and listed in biodiversity red lists; for example, in Colombia there is a partial list of 207 endangered orchids (Calderón 2007). There are several critical aspects of orchid biology that contribute to those threats. Orchid conservation requires the consideration of two bottlenecks in the orchid's life cycle: seed germination and pollination (Tremblay \& Otero 2009). Orchids depend on specific fungi for seed germination (Otero et al. 2002; 2004; 2007) that may have had complex co-cladogenic processes (Otero et al. 2011); however, there is still much to learn about many orchid mycorrhizal interactions, especially in the tropics (Otero \& Bayman 2007). In the Andes, the highest threat to orchid conservation is habitat loss; nevertheless, pollination is also crucial.

Orchids are renowned for the complex and intriguing pollination mechanisms adapted to pollination by animals (Darwin 1885, van der Pijl \& Dodson 1966, Singer 2002, Borba \& Braga 2003), especially insects (Dressler 1981). It is now well known that bees and wasps are responsible for about $60 \%$ of the pollination of the family (Williams 1982, Ackerman 1983; Whitten et al. 1993; Camargo et al. 2006), flies pollinate $15-25 \%$ of species (Borba \& Semir 2001), and Lepidoptera, Coleoptera and birds pollinate about 1525\% remaining (van der Pijl \& Dodson 1966; Singer et al. 2007; Cuartas-Domínguez \& Medel 2010). Orchids may provide a variety of rewards to their pollinators, such as oils, floral fragrances and occasionally pollenlike substances (Neiland \& Wilcock 1998; Pansarin 2008); however, nearly a third of orchid species provide no floral resources, and depend on various forms of deception for pollination (Ackerman 1986; Nilsson 1992; Cozzolino \& Widmer 2005). One of the most common means of deception, sexual mimicry, is reported in about 20 genera of Orchidaceae with various pollinator types such as solitary and social bees, wasps, beetles and flies (Dafni 1984; Sasaki et al. 1991). This mechanism includes visual and/or olfactory features attracting insects. The best known cases of reproductive deception involve pseudo-copulation, a phenomenon unique to orchids (Nilsson 1992). Where, flowers mimic female structures and chemical pheromones of certain insects (Singer et al. 2004; Blanco \& Barboza 2005), and are pollinated by male insects seeking a mate (Dressler 1981; Williams \& Whitten 1983; Singer 2002). The emission of fragrances that resemble the insect sexual pheromones for reproduction is an important factor associated with the mimicry, including mating or oviposition sites (Albores-Ortiz \& Sosa 2006; Barbosa et al. 2009; Barriault et al. 2010; Endara et al. 2010 Peakall et al. 2010).

Some studies suggest that the subtribe Pleurothallidinae (Orchidaceae: Epidendreae) is mainly adapted to pollination by Diptera species (van der Pijl \& Dodson 1966; Chase 1985; Duque 1993; Borba \& Semir 2001; Blanco \& Barboza 2005; Pupulin et al. 2012), with several reports of deception by sexual mimicry (Christensen 1994; Blanco \& Barboza 2005). Borba \& Semir (2001) studied four Brazilian species and reported different fragrances and pollinator activities. Acianthera johannensis (Barb. Rodr.) Pridgeon \& M.W. Chase (as Pleurothallis johannensis Barb. Rodr.) and Acianthera fabiobarrosii (Borba \& Semir) F. Barros \& F. Pinheiro (as P. fabiobarrosii Borba \& Semir) are pollinated by females of the genera Tricimba (Chloropidae) and have a diurnal smell of fish and no nectar production, while Acianthera teres (Lindl.) Borba (as P. teres Lindl.) and Acianthera ochreata (Lindl.) Pridgeon \& M.W. Chase (as P. ochreata Lindl.) have a diurnal smell of rancid cheese and produce nectar like liquid at the base of the labellum. The latter are pollinated by Megaselia spp. (Phoridae) (Borba \& Semir 2001), Acianthera adamantinensis (Brade) F. Barros (as Pleurothallis adamantinensis Brade) has a dog feces odor and is pollinated by flies Hippelate ssp. (Chloropidae) (Borba $\&$ Semir 2001). Those five species had high genetic variability showing a high percentage of polymorphic loci ranged from 50 to $83 \%$, with a mean number of alleles per locus between 2.1 and 3.8, and a mean 
heterozygosity (He) ranged from 0.25 to 0.43 (Borba et al. 2001). Acianthera johannensis, A. fabiobarrosii, and $A$. adamantinensis showed a low level of genetic structuring while $A$. teres and A. ochreata showed high genetic structuring (Borba et al. 2001). However, the actual evidence has not been applied for conservation purposes, but in recent years the genus had been subdivided in smaller groups.

Pleurothallis marthae (Luer \& Escobar) Luer is an interesting research model because it has relatively large flowers of $2 \mathrm{~cm}$ that facilitate observation and is a frequent species in Yotoco Nature Reserve, Colombia. Little information is reported in the literature on this species. It is listed in the CITES Appendix II (W3Tropicos, accessed on Dec 2012) and is endemic to Colombia. Recently it was recorded from Yotoco Nature Reserve (Escobar 2001; Pérez-Escobar et al. 2009). The species grows as both an epiphyte near the ground (no more than one meter high) and a terrestrial plant, at 1400-1800 m elevation in mountain forest. The objectives of this study are to describe the pollination system and mechanisms of pollinator attraction of $P$. marthae.

\section{Material and Methods}

Study species. - Pleurothallis marthae is a terrestrial species or rarely epiphytic, without pseudobulbs, leaves broad, deeply cordate (Luer \& Escobar 1996), it has a little bundle of pink flowers on the base of the leaf. The flowers are relatively large for the genus. This species was described as $P$. marthae by Luer \& Escobar from a collection by E. Valencia from Garrapatas (Valle del Cauca, Colombia) (Luer \& Escobar 1996) and then transferred to Acronia Luer (2005). As Acronia is not broadly accepted we use Pleurothallis. P. marthae has flowers with two different coloration patterns and morphology (morphs). The first (yellow-morph) has yellowish dorsal sepal the broadly ovate, obtuse, concave, with translucent horizontal lines and dots, the lateral sepals completely connate (synsepal) is lilac, with glandular trichomes, petals rose, concave, with glandular trichomes too, lip light rose, thick, convex, transversely obovate. The second (pink-morph) has a pink dorsal sepal with translucent horizontal lines and dots, the synsepal is magenta with glandular trichomes, the petals are larger than the yellow-morph (Fig. 1) and the lip is similar to yellow-morph. In both morphs the column is short and cream-colored with an apical anther and a bilobed stigma (Fig. 1).

Study site. - We did this study at the Yotoco Forest Reserve (YFR), located on the eastern slope of the western Cordillera de Los Andes in Colombia, in the municipality of Yotoco. The site was situated in remnants of the subtropical wet-dry transition forest of Valle del Cauca $\left(3^{\circ} 50^{\prime} \mathrm{N}, 76^{\circ} 20^{\prime} \mathrm{W}\right)$ at an elevation of $1400-1600 \mathrm{~m}$. Average annual temperature is $20^{\circ} \mathrm{C}$; average annual precipitation is $1500 \mathrm{~mm}$; and relative humidity averages $85 \%$ (Escobar 2001).

Two populations were surveyed, accounting 250 individuals in total; each individual was marked with an aluminum tag with a previously assigned code. Individuals were considered genets if all shoots were attached to a single rhizome and were physically separate from other plants. Individuals were characterized by size class according to the length of the longest shoot. The classes are the following: SIZE I $(6-20 \mathrm{~cm})$, SIZE II $(21-40 \mathrm{~cm})$, SIZE III $(41-60 \mathrm{~cm})$, SIZE IV $(>61 \mathrm{~cm})$.

Reproductive events. - The numbers of open flowers $(\mathrm{OF})$, pollinaria removed (PR), closed stigmas (CS) and swollen ovaries (SO) were recorded weekly as indirect evidence of reproductive effort and pollination events. As the data were not normally distributed, the differences between size classes for each reproductive event were analyzed using a Kruskal-Wallis test. The correlation between pollinator activity and flowering anthesis was evaluated with a linear regression. All data were analyzed with Statgraphics ${ }^{\circledR}$ Plus Version $5.1 \circledR$.

Flower visits. - Observations were initially made between 0600 and $1800 \mathrm{~h}$ to identify periods of activity of flower visitors and pollinators. Very low activity was observed during the day, so the observation period were extended until $2000 \mathrm{~h}$. Visitors were observed using red light located two meters from the plants to broaden the spectrum of light to avoid pollinator disturbance they were highly sensitive to direct illumination. With these additional hours we discovered visitation was nocturnal, so all further nocturnal observation periods were done between $1800-0600 \mathrm{~h}$, for a total of 97 hours of observation (not including the diurnal times). For 30 individuals, the time of arrival of visitors was recorded, duration of visit, behavior within the flower, and number of visitors, and additionally video and 


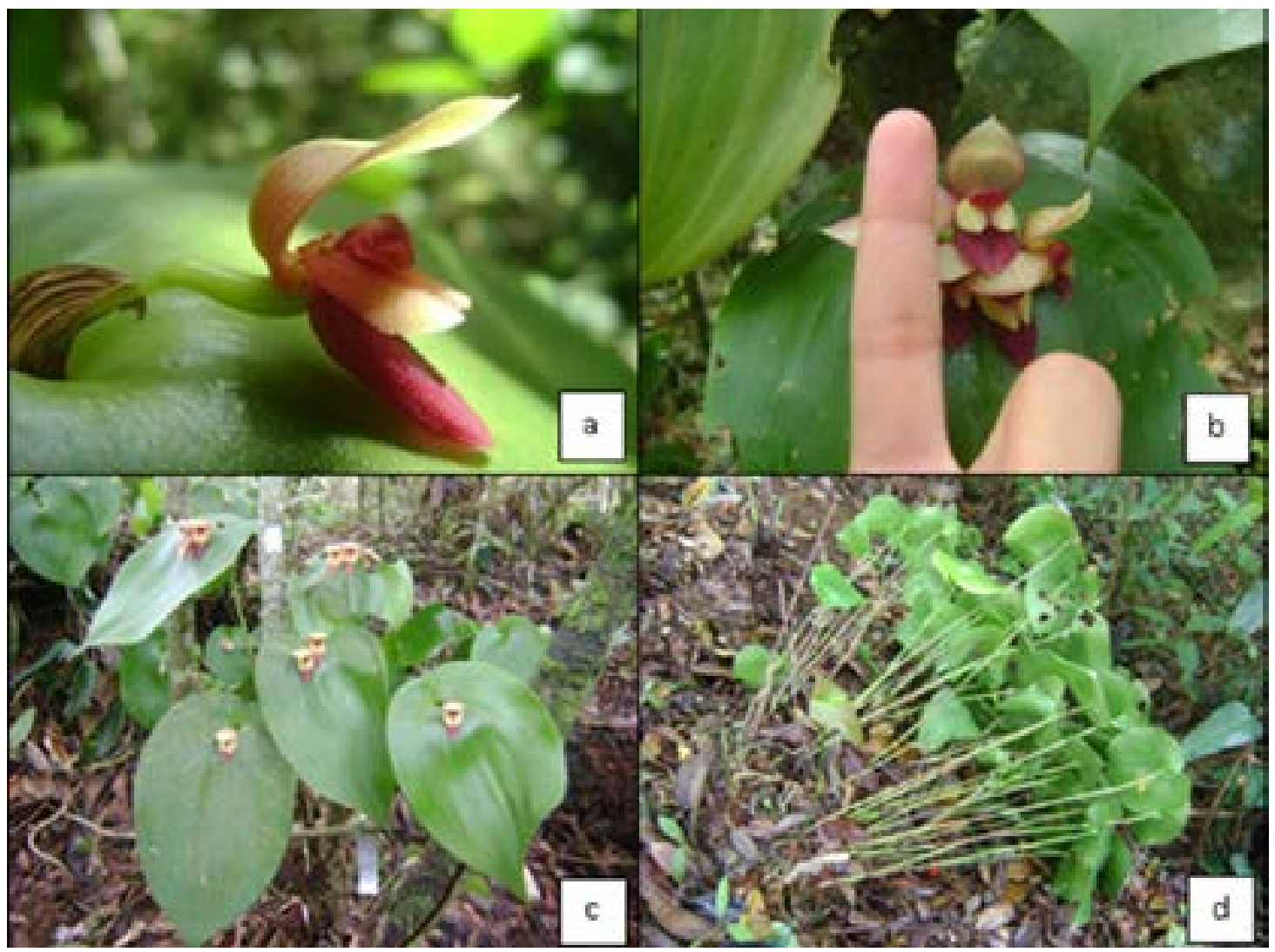

Figure 1. Flower of Pleurothallis marthae: a) lateral view, b) frontal view, c) two color morphs, d) Habit of Pleurothallis marthae.

photographic records. Flower visitors and pollinators were differentiated by behavior. Floral visitors were collected in plastic vials, transported to the zoology laboratory at Universidad of Caldas where high resolution macro photos were taken. As Colombian law prohibits exportation of wild biological material, Dr Sarah Siqueira de Oliveira, at the University of São Paulo identified the specimens from the photographs.

Osmophore detection.. - From each of the populations, we collected fresh flowers from 10 individuals and stained in a bath of neutral red 1:1000 for 20 minutes (Stern et al. 1986) to detect scent-secreting glands (osmophores) or nectaries as neutral red indicate sites that is metabolically active (Kearns \& Inouye 1993).

Reproductive system. - We bagged 40 flower buds of 20 plants with net mesh to exclude insect visitors. Once the flowers were in anthesis and receptive, as indicated by a wet and sticky stigmatic surface, we performed the following hand-pollination treatments: autogamy (removal of pollinaria from a flower and pollen transfer to the same flower); geitonogamy (removal of pollinaria from one flower and pollen transfer to another flower of the same plant); xenogamy (removal of pollinaria from a flower and pollen transfer to a flower of another plant); and natural pollination. All treatments with the exception of the natural pollination treatment were bagged again to prevent insect visitors impacting the results. Pollinations were monitored until fruits matured or aborted. We analyzed differences among treatments with a non-parametric Kruskal-Wallis test.

Results. Flower buds develop in 10-15 days, and flowers remain open for 10-12 days, provided that pollination did not occur. The flowers produce funguslike odor and lightly sweet nectar at night time. Anthesis of $P$. marthae began at 18:30 when flowers began to release a fungus-like odor (as detected by the human 


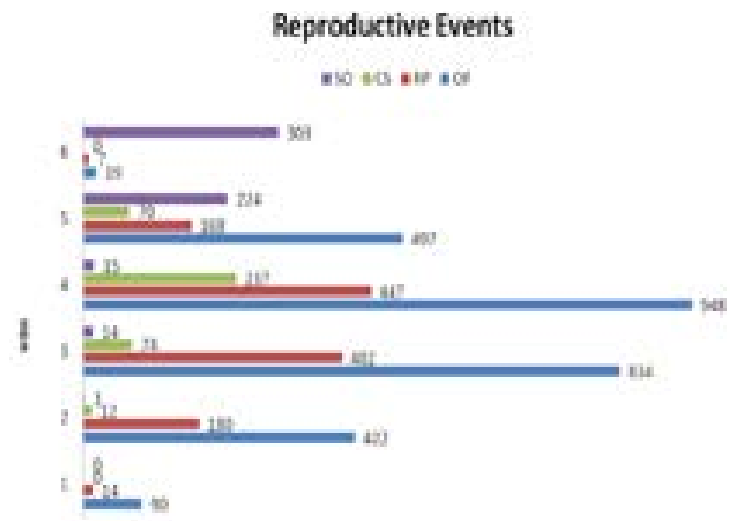

FIGURE 2. Linear regression of the number of flowers per reproductive season vs. number of fruits.

nose) and nectar secreted by the lip. As time passed the smell gradually increased in intensity, and peaked at 23:30. There after the intensity decreased until approximately 05:00, when it became imperceptible. The fluid secreted from the lip remained in the flower from 19:00 until 09:00.

Reproductive events. - The species flowered from early May through mid June (six weeks), with a peak at the fourth week. There were significant differences in weekly flower abundances among size classes (H test, P-value $=0.03$ ) with small individuals producing fewer flowers than the large ones. Nevertheless, the number of pollinia removed $(\mathrm{H}$ test, $\mathrm{P}$-value $=0.14)$, stigmas closed $(\mathrm{H}$ test, $\mathrm{P}$-value $=0.31)$ and ovaries swelled $(\mathrm{H}$ test, $\mathrm{P}$-value $=0.19)$ did not differ significantly. There was a significant relationship between weekly abundance of flowers and abundance of pollinators visiting flowers during the anthesis period $(\mathrm{H}$ test, P-value $=0.02$ ). There was a correlation between number of pollinator visit and the number of flowers in anthesis per reproductive season (Fig. 2). The time from pollination to fruit dehiscence was between 9 and 10 weeks. The reproductive events did not differ statistically between two different coloration patterns (morphs) observed ( $\mathrm{H}$ test, $\mathrm{P}$-value $>0.05$ ).

Flower visitors. - The most common flower diurnal visitors were herbivorous caterpillars (Lepidoptera: Geometridae), which feed on buds, ovaries, and fruits in early developmental stages. We also observed adults of two Orthoptera species: Eumastacidae and Acrididae feeding on flowers and foliage. We also saw Heliconius

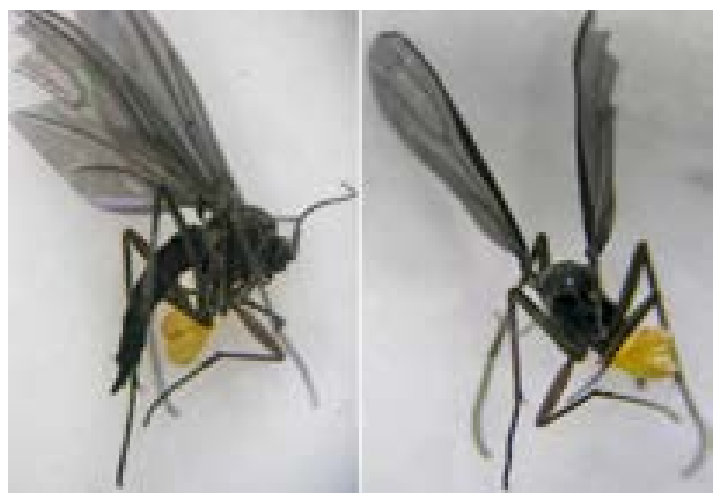

FIgURe 3. Bradysia sp. with Pleurothallis marthae pollinaria adhered to the dorsal side of the thorax.

cydno cydnides Staudinger (Lepidoptera: Heliconidae) visiting several flowers in a typical foraging behavior and two species of spiders, Araneidae and Thomisidae, families known to hunt pollinators. Occasionally, we observed ants eating the nectar from the lip.

We observed two pollinators species, Bradysia sp. (Diptera: Sciaridae) and Mycetophila sp. (Diptera: Mycetophilidae), both fungus gnats. The Bradysia sp. (Fig. 3) visited several flowers on the same plant (Fig. 4) by first landing on the synsepal, and then crossing the petals to consume the nectar on the labellum for a few seconds. Subsequently, the gnat contacted the apex of the column and probably causing the pollinarium to adhere to the ventral section of the thorax. Visits of Bradysia sp. were very brief (10 seconds) and were only observed on two occasions, in one of them, the individual had two pollinaria attached.

The Mycetophila sp. (Fig. 5) was presumably attracted by the fungus-like floral fragrance. The gnats landed on the flower (synsepal, lip, petals, or column) and began a series of wing and thorax movements while lifting the hind legs (Fig. 6), and sometimes moving the abdomen as if to oviposit. Probably pollinaria adhere to the ventral part of the thorax when individuals court and mate. Individuals stayed on the flower for a long time (sometimes overnight). We often observed many individuals of Mycetophila sp. visiting the flower at the same time (10 individuals), observed 47 individuals in total. On several occasions we observed mating among the Mycetophila sp. but we did not observe pollination events. Nevertheless, indirect evidence of their 

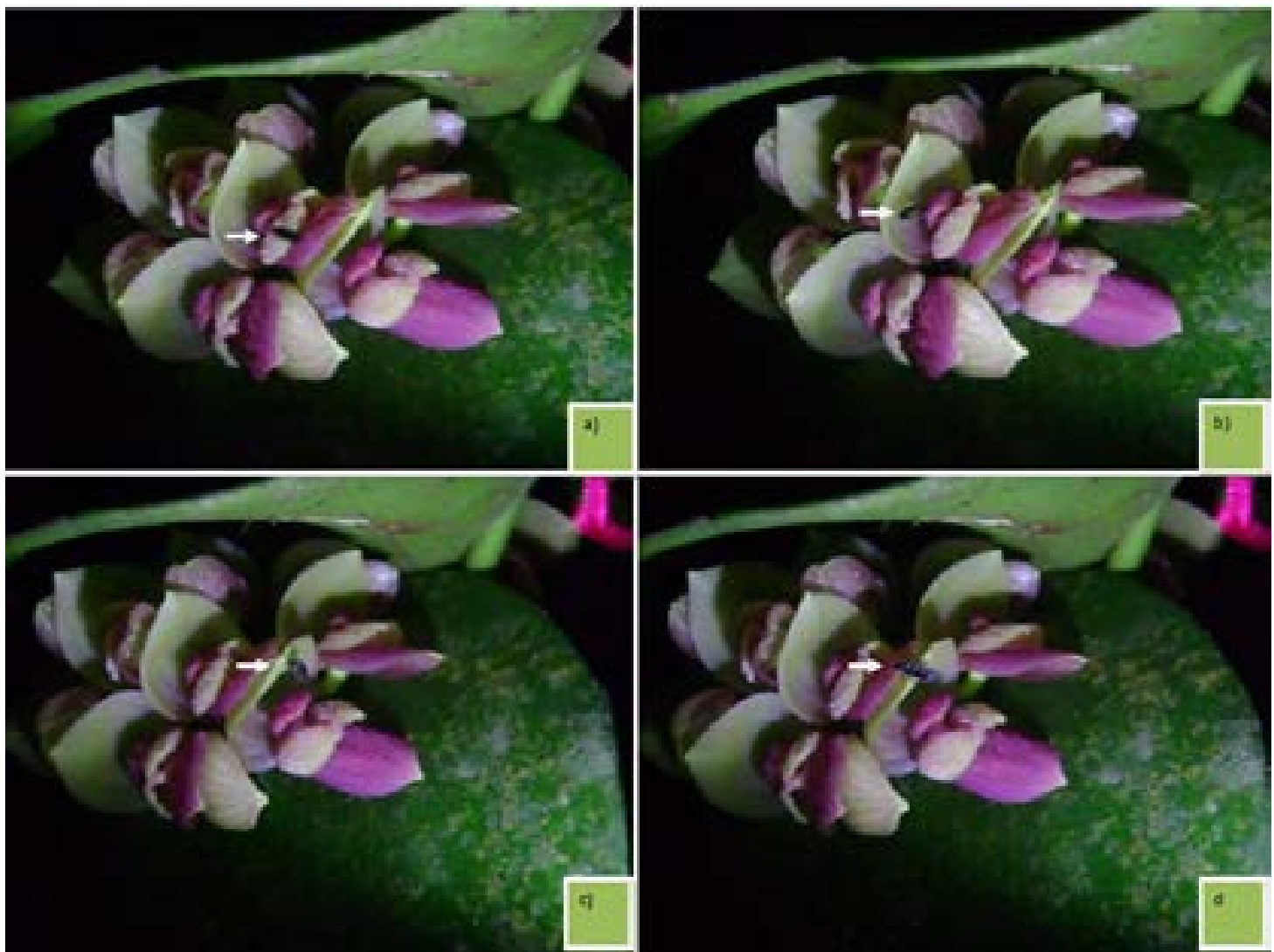

Figure 4. Visit sequences of Bradysia sp. in Pleurothallis marthae flowers. a - Bradysia sp. arriving to the petals and facing to the labellum; b - Bradysia sp. consuming nectar from the labellum; c — Bradysia sp. crossing by the column and climbing by the lower part of the dorsal sepal; $\mathrm{d}$ - Bradysia sp. crossing by the lower part of the dorsal sepal to exit the flower.

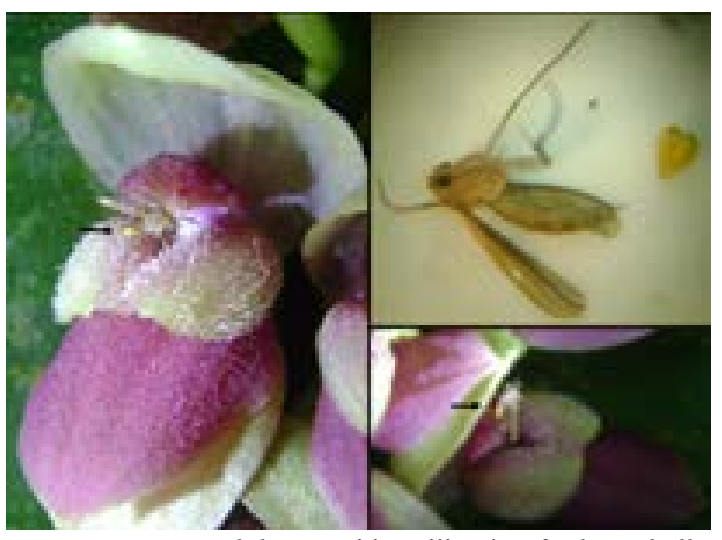

FIgURE 5. Mycetophila sp. with pollinaria of Pleurothallis marthae. a - Mycetophila sp. in a flower of Pleurothallis marthae with a pollinarium in the ventral part of the thorax. b - Close up of Mycetophila sp. and pollinarium. The pollinarium was detached of the insect during the specimen manipulation. pollination activity was obtained from the collection from the field of these diptera species with P. marthae pollinarium attached.

Osmophore detection. - Osmophores were detected in the epidermis of synsepals, dorsal sepal and petals, with an obvious presence in scattered spots located mainly at the edges of the structure (Fig. 7). The petal tips had glandular trichomes.

Reproductive system. - Our hand-pollination experiments indicated that Pleurothallis marthae is self-compatible. Self-pollination treatment within a flower produced $60 \%$ fruit set; pollination between flowers of the same clump produced $50 \%$ fruit set; cross-pollinations had $60 \%$ fruit set and natural pollination produced $40 \%$. No significant differences were observed between the different treatments $(\mathrm{H}$ test, $\mathrm{P}$ value $>0,05)$. 


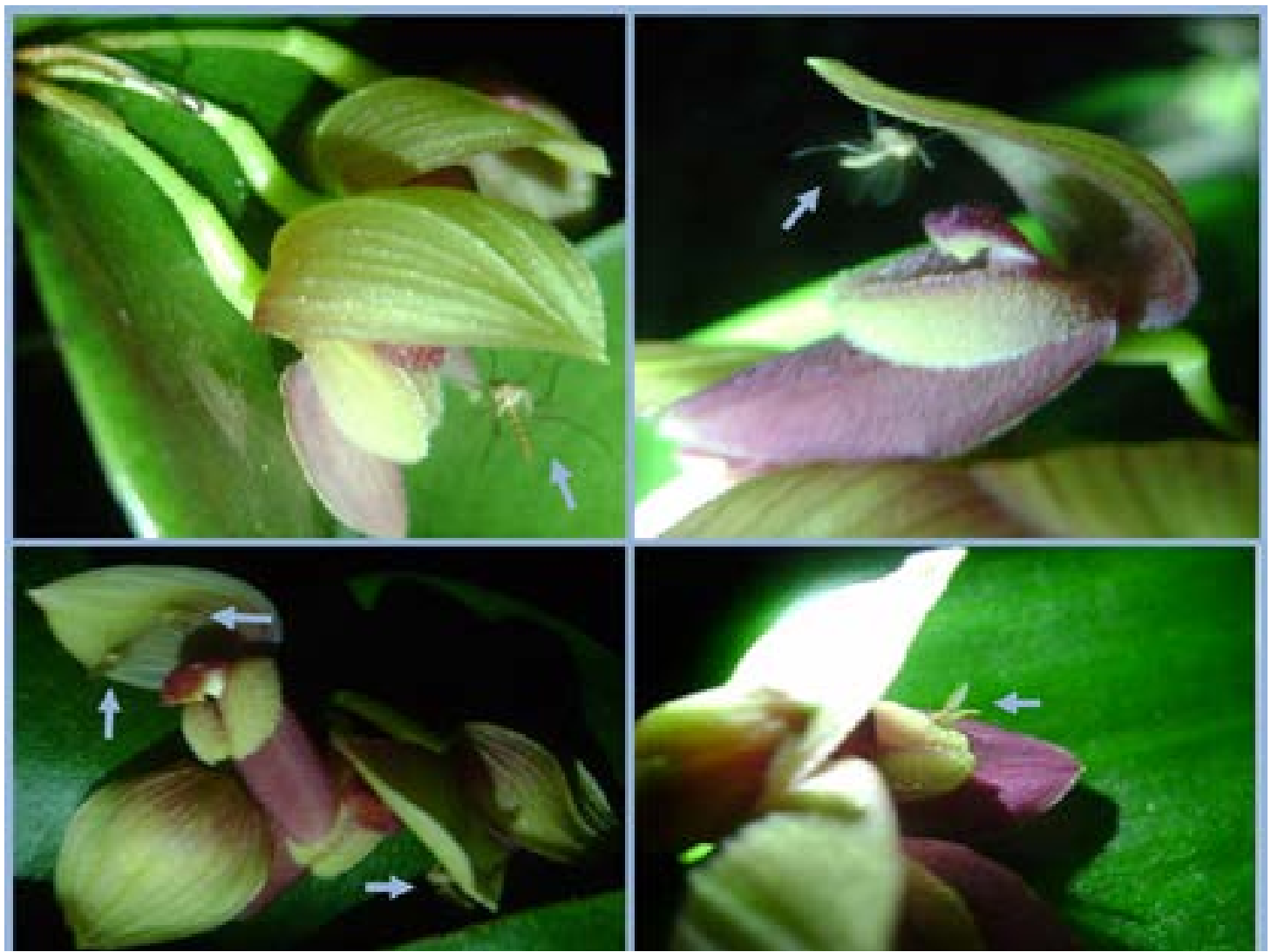

FIGURE 6. Display of Mycetophila sp. in Pleurothallis marthae flowers.

Discussion. Base on the finding of Pleurothallis marthae is probably pollinated by two species of fungus gnats: Mycetophila sp. and Bradysia sp. Visitors can remove pollinia and not necessarily be pollinators, nevertheless, form in which deposited pollinia, court and mate in the flowers, fungus-like odor, absence of other species through visits and biology of fungus gnat, we believe that they are pollinators. This case is similar to that found by Endara et al. (2010), in this work on pollination of Dracula lafleurii Luer \& Dalström and Dracula felix (Luer) Luer, authors argue that the pollination process occurs when individuals of Zygothrica perform court and mate in the flowers.

The effectiveness of fungus gnats orchid as pollinators had been briefly documented by van der Pijl and Dodson (1966) on the pollination of Stelis aemula Schltr. Most recently, other orchids had been reported as fungus gnats pollinated, for example Lepanthes glicensteinii is pollinated by Bradysia floribunda in Costa Rica (Blanco \& Barboza 2005), Octomeria crassifolia is pollinated by Bradysia sp. in Brazil (Barbosa et al. 2009). In California, Listera cordata (= Neottia cordata; Orchidoideae) is pollinated by Mycetophila sp. and Sciara sp. (Ackerman \& Mesler 1979).

Mycetophila forms distinct groups of closely related species, which are within the group usually separable only by the characters on the male terminalia. Mycetophila is one of the most abundant families of order Diptera encompassing more than 3000 described species, with a world-wide distribution (Gaston 1991). Pleurothallis marthae has flowers with two different coloration patterns (morphs). Pollination success was detected equally in both morphs, suggesting that color is not a key factor determining reproductive success, and supporting the hypothesis that both fragrances and nectar are key attracting factors. Nevertheless, we found a positive relationship between flower abundance and the number of pollinator visits. This may be because with a greater number of flowers there 


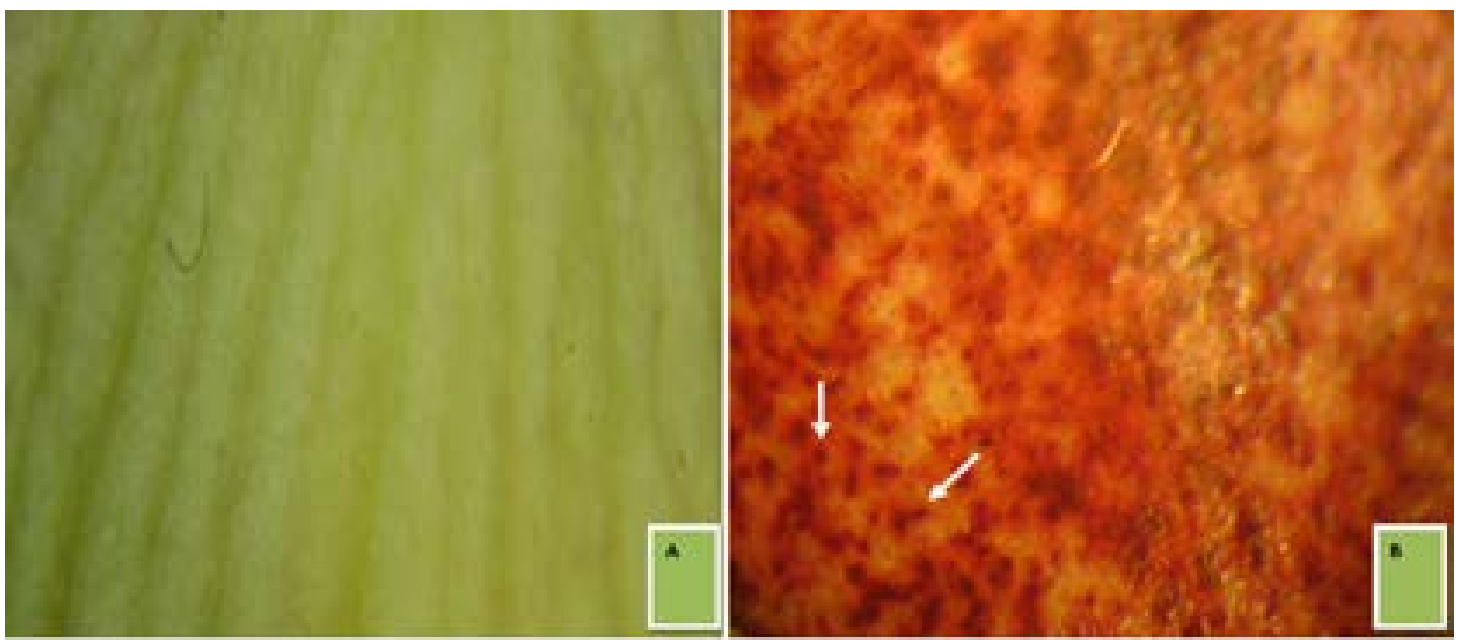

FiguRE 7. Portion of the dorsal sepal (a) before and (b) after staining with neutral red. Arrows shows the presence of osmophores and/or nectaries in the adaxial side of the sepal.

is likely to be an increase in the emission of aroma and possibly a greater supply of nectar, making these flowers more effective at attracting pollinators.

Pleurothallis marthae seems to mimic the smell of a fungus; this case had been reported in Zootrophion sp. (Orchidaceae) and coincides with the syndrome of sapromyophily (pollination syndrome of flowers producing smell of decaying flesh) proposed by Faegri \& van der Pijl (1971).

Although oviposition behavior was observed by Mycetophila sp., we did not observe eggs or larvae under microscope, which suggests a mechanism in which the flowers attract female flies, and those females at the same time attract males (Ackerman \& Mesler 1979). Mycetophila sp. was observed mating on the flowers on several occasions. Displaying Mycetophila sp. were most commonly observed on the specific parts of the flower in which we located the scent glands (osmophores), suggesting that the attraction of this species occurs by the emission of a fragrance. Additionally, floral display was also very important as plants with more open flowers had higher fitness that may be complementary.

Both pollinator species are commonly known as fungus gnats because they are almost always dependent upon fungal substrates for larval development. The Bradysia sp. may have been initially attracted by the smell and then by the presence of nectar, which may be a mechanism to keep the flies on flowers for longer periods of time to enhance the probability of pollination (de Melo et al. 2010).

Our results on the reproductive system suggest that $P$. marthae is self-compatible; this finding is compatible with the observed behavior of pollinators, whose continued presence at a single flower and at the flowers of a single plant is likely to promote $P$. marthae reproduction. This phenomenon has also been observed in other species (Mesler et al. 1980; Borba \& Semir 2001; Singer 2001; Barbosa et al. 2009). While we did not conduct a pollination treatment to test for self-pollination, fruit and seed production in most self-compatible orchids are pollinator-dependent, and P. marthae is likely no exception (Rodríguez-Robles et al. 1992; Singer \& Zasima 1999; Singer 2001; Singer et al. 2004).

The natural fruit set observed in this study was $60 \%$. This value is higher than the ranges suggested by Neiland \& Wilcock (1998) for tropical orchids, although those reported for Listera cordata $61-78 \%$ (Ackerman \& Mesler 1979) and Habenaria parviflora 93.3-96.7\% (Singer 2001), species pollinated by Diptera, are higher. Together, these findings suggest that Diptera pollination can be a very favorable strategy for orchids.

We present new evidence of fly pollination in the genus Pleurothallis. Fly pollination had already been reported for species Lepanthes glicensteinii Luer, Listera cordata (L.) R. Br., Tolmiea menziesii (Pursh) Torr. \& A. Gray, Asarum caudatum Lindl., Dracula lafleurii Luer \& Dalström and Dracula felix (Luer) Luer, Specklinia pfavii (Rchb.f.) Pupulin \& Karremans 
and Specklinia spectabilis (Ames \& C.Schweinf.) Pupulin \& Karremans (Mesler et al. 1980; Lu 1982; Goldblatt et al. 2004; Okuyama et al. 2004; Endara et al. 2010, Pupulin et al. 2012), revealing them to be very important pollination vectors that have highly specialized relationships with the plants they pollinate. As far as we know, our study is the first case suggesting fungal-like odors may be involved in attracting pollinators in Pleurothallis and the second for the Subtribe Pleurothallidinae (Christensen 1994). It is the first report of nocturnal pollination of the genus and species pollinated by fungus gnats. Lepanthes may be nocturnally pollinated too (Tremblay \& Ackerman 2007). Further studies in our research group are focused in the understanding of the fragrance composition of of $P$. marthae flowers. The knowledge of this obligatory interspecific interactions is critical for the conservation management of this Colombian endemic orchid, P. marthae; of course, we have to include the conservation of their nocturnal fungus gnat pollinators.

ACKNOWLEDGEMENTS. The authors are thankful for the Mobility grant awarded to the first author by Santander Universities. We thank Sarah Siqueira de Oliveira for the identification of Diptera; Carlos Alberto Jaramillo, Valentín Hidalgo and the staff of the Yotoco Forest Reserve of the Universidad Nacional de Colombia-Palmira for assistance in the development of this study; James D. Ackerman, Nicola S. Flanagan, Paul Bayman, Nhora Helena Ospina and Marcela Cuartas for their comments and contributions to the manuscript; and the Grupo de Investigación en Orquídeas, Ecología y Sistematica Vegetal (COL 0066015) of the Universidad Nacional de Colombia-Palmira for logistical support.

\section{LiterATURE CITED}

Ackerman, J.D. 1983. Specificity and mutual dependency of the orchid-euglossine bee interaction. Biological Journal of the Linnean Society 20: 301-314.

Ackerman, J.D. 1986. Mechanisms and evolution of fooddeceptive pollination systems in orchids. Lindleyana 1: 108-13.

Ackerman, J.D. \& M.R. Mesler. 1979. Pollination Biology of Listera cordata (Orchidaceae). American Journal of Botany 66: 820-824.

Albores-Ortiz, O. \& V. Sosa. 2006. Polinización de dos especies simpátricas de Stelis (Pleurothallidinae,
Orchidaceae). Acta Botánica Mexicana 74: 155-168.

Barbosa, A.R., M.C. de Melo \& E.L. Borba. 2009. Self-incompatibility and myophily in Octomeria (Orchidaceae, Pleurothallidinae) species. Plant Systematics and Evolution 283: 1-8.

Barriault, I, D. Barabe, L. Cloutier \& M. Gibernau. 2010. Pollination ecology and reproductive success in Jack-in-the-pulpit (Arisaema triphyllum) in Quebec (Canada). Plant Biology 12: 161-171.

Blanco, M.A. \& G. Barboza. 2005. Pseudocopulatory Pollination in Lepanthes (Orchidaceae: Pleurothallidinae) by Fungus Gnats. Annals of Botany 95: 763-772.

Borba, E.L. \& P.I. Braga. 2003. Biologia reprodutiva de Pseudolaelia corcovadensis (Orchidaceae): melitofilia e autocompatibilidade em uma Laeliinae. Revista Brasileira de Botânica 26: 541-549.

Borba, E.L., J.M. Felix, V.N. Solferini \& J. Semir. 2001. Fly-pollinated Pleurothallis (Orchidaceae) species have high genetic variability: evidence from isozyme markers. American Journal of Botany 88: 419-428.

Borba, E.L. \& J. Semir. 2001. Pollinator Specificity and Convergence in Fly-pollinated Pleurothallis (Orchidaceae) Species: A Multiple Population Approach. Annals of Botany 88: 75-88.

Calderón-Saenz E. 2007. Libro rojo de plantas de Colombia. Volumen 6: Orquídeas, primera parte. Serie de Libros Rojos de Especies Amenazadas de Colombia. Bogotá, Colombia. Instituto Alexander von HumboldtMinisterio de Ambiente, vivienda y desarrollo territorial. $828 \mathrm{p}$.

Camargo, E., V, Silva \& E. Leit. 2006. Reproductive biology of two Cattleya (Orchidaceae) species endemic to north-eastern Brazil. Plant Species Biology 21: 85-91.

Canadell, J. \& I. Noble. 2001. Challenges of a changing earth. Trends in Ecology and Evolution 16: 664666.

Chase, M.W. 1985. Pollination of Pleurothallis endotrachys. American Orchid Society-Bulletin 54: 431-434.

Christensen, D.E. 1994. Fly pollination in the Orchidaceae. In J. Arditti [ed.], Orchid Biology: Reviews and perspectives, VI, 415-454. (John Wiley \& Sons. New York, USA.

Cozzolino, S. \& A. Widmer. 2005. Orchid diversity: an evolutionary consequence of deception? Trends in Ecology and Evolution 20: 487-494.

Cuartas-Domínguez, M. \& R. Medel. 2010. Pollinatormediated selection and experimental manipulation of the flower phenotype in Chloraea bletioides. Functional Ecology 24: 1219 -1227. http://dx.doi.org/10.1111/ j.1365-2435.2010.01737.x 
Dafni, A. 1984. Mimicry and Deception in Pollination. Annual Review of Ecology and Systematic 15: 259278.

Darwin, C.D. 1885. The various contrivances by which orchids are fertilized by insects. John Murray, London, UK.

Dressler, R.L. 1981. The Orchids, natural history and classification. The Smithsonian Institution, Washintong DC, USA.

Duque, O. 1993. Polinización en Pleurothallis. Orquideología 19: 55-69.

Endara, L., Grimaldi, D. A., \& Roy, B. A. 2010. Lord of the flies: pollination of Dracula orchids. Lankesteriana 10: $1-11$.

Escobar, E. 2001. Presentación de Yotoco "Reserva Natural" Flora: Plantas Vasculares. Universidad Nacional de Colombia, Palmira, Colombia.

Faegri, K. \& L. van der Pijl. 1979. The principles of pollination biology. Oxford: Pergamon Press.

Flanagan, N.S., R. Peakall, M.A. Clements \& J.T. Otero. 2006. Conservation of taxonomically difficult species: the case of the Australian orchid, Microtis angusii. Conservation Genetics 7: 847-859.

Gaston, K.J. 1991. The magnitude of global insect species richness. Conservation Biology, 5: 283-296.

Goldblatt, P., P. Bernhardt, P. Vogan \& J.C. Manning. 2004. Pollination by fungus gnats (Diptera: Mycetophilidae) and self-recognition sites in Tolmiea menziesii (Saxifragaceae). Plant Systematics and Evolution 244: 55-67.

Govaerts, R., J. Pfahl, M.A. Campacci, D. Holland-Baptista, H. Tigges, J. Shaw, P. Cribb, A. Geore, K. Kreuz \& J. Wood. 2012. World checklist of Orchidaceae. The Board of Trustees of the Royal Botanic Gardens, Kew. http://www.kew.org/wcsp/monocots/ [accessed 24 June 2012].

Kearns, C.A. \& D.W. Inouye. 1993. Techniques for Pollination Biologists. University Press of Colorado, Colorado, USA.

Kearns, C.A., D.W. Inouye \& N.M. Waser. 1998. Endangered Mutualism: the conservation of plantpollinators interactions. Annual Review of Ecology and Systematics 29: 83-112.

Lu, K.L. 1982. Pollination Biology of Asarum caudatum (Aristolochiaceae) in Northern California. Systematic Botany 7:150-157.

Luer, C.A. \& R. Escobar. 1996. Nuevas especies de Pleurothallis de Colombia. Orquideología 20: 68-71.

Luer, C.A. 2005. Icones pleurothallidinarum XXVII. Dryadella and Acronia section MacrophyllaeFasciculatae: addenda to Acianthera, Andinia,
Dracula, Dresslerella, Lepanthes and Masdevallia new taxa, validation of taxa, errata. Missouri Botanical Garden, St. Louis.

de Melo, M.C., E.L. Borba \& P.E. Sousa. 2010. Morphological and histological characterization of the osmophores and nectaries of four species of Acianthera (Orchidaceae: Pleurothallidinae). Plant Systematic Evolution 286: 141-151.

Mesler, M.R., J.D. Ackerman \& K.L. Lu. 1980. The effectiveness of fungus gnats as pollinators. American Journal of Botany 67: 564-567.

Neiland, M.R. \& C. Wilcock. 1998. Fruit Set, Nectar Reward, and Rarity in the Orchidaceae. American Journal of Botany 85: 1657-1671.

Nilsson, L.A. 1992. Orchid pollination biology. Trends in Ecology and Evolution 7: 255-259.

Okuyama, Y., M. Kato, N. Murakami. 2004. Pollination by fungus gnats in four species of the genus Mitella (Saxifragaceae). Botanical Journal of the Linnean Society 144: 449-460.

Otero, J.T., J.D. Ackerman \& P. Bayman. 2002. Diversity and host specificity of endophytic Rhizoctonia-like fungi from tropical orchids. American Journal of Botany 89: 1852-1858.

Otero, J.T., J.D. Ackerman \& P. Bayman. 2004. Differences in mycorrhizal preferences between two tropical orchids. Molecular Ecology 13: 2393-2404.

Otero, J.T. \& P. Bayman. 2007. Mycorrhizae in orchid conservation. In: E Calderón-Sáens [ed.], The Red Book of Orchids of Colombia, V, 6: Orchids, First Part. Series The Red Book Species of endangered species of Colombia, 771-796. Instituto Alexander von Humboldt, Ministerio de Ambiente, Vienda y Desarrollo Territorial, Bogota, Colombia.

Otero, J.T., N.S. Flanagan, E.A. Herre, J.D. Ackerman, P. Bayman. 2007. Widespread mycorrhizal specificity correlates to mycorrhizal function in the neotropical, epiphytic orchid, Ionopsis utricularioides (Orchidaceae). American Journal of Botany 94: 19441950.

Otero, J.T., P.H. Thrall, M.A. Clements, J.T. Miller \& J.J. Burdon. 2011. Co-diversification of Orchids (Pterostylidinae) and their Associated Mycorrhizal Fungi. Australian Journal of Botany 59: 480-497.

Pansarin, E.R. 2008. Reproductive biology and pollination of Govenia utriculata: A syrphid fly orchid pollinated through a pollen-deceptive mechanism. Plant Species Biology 23: 90-96.

Peakall, R., D. Ebert, J. Poldy, R.A. Barrow, W. Francke, C.C. Bower \& F.P. Schiestl. 2010. Pollinator specificity, floral odour chemistry and the phylogeny of Australian 
sexually deceptive Chiloglottis orchids: implications for pollinator-driven speciation. New Phytologist 188: 437-450.

Pérez-Escobar, O.A., E. Parra-Sanchez \& P. Ortiz-Vadivieso. 2009. Inventario orquideológico de la Reserva Bosque de Yotoco, Valle del Cauca. Acta Agronómica 58: 189196.

Pupulin, F., A.P. Karremans \& B. Gravendeel. 2012. A reconsideration of the empusellous species of Specklinia (Orchidaceae: Pleurothallidinae) in Costa Rica. Phytotaxa 63: 1-20.

Rodríguez-Robles, J.A., E.J. Meléndez \& J.D. Ackerman. 1992. Effects of display size, flowering phenology, and nectar availability on effective visitation frequency in Comparettia falcata (Orchidaceae). American Journal of Botany 79: 1009-1017.

Sasaki, M., M. Ono, T. Asada \& T. Yoshida. 1991. Oriental orchid (Cymbidium pumilum) attracts drones of the Japanese honeybee (Apiscerana japonica) as pollinators. Experientia 47: 1229-1225.

Singer, R.B. 2001. Pollination biology of Habenaria parviflora (Orchidaceae: Habenariinae) in Southeastern Brazil. Darwiniana 39: 201-207.

Singer, R.B. 2002. The pollination mechanism in Trigonidium obtusum Lindl. (Orchidaceae: Maxillariinae): Sexual mimicry and trap-flowers. Annals of Botany 89: 157163.

Singer, R.B. \& M. Sazima. 1999. The pollination mechanism in the 'Pelexia alliance' (Orchidaceae:Spiranthinae). Botanical Journal of the Linnean Society 131: 249-262.

Singer, R.B., A. Flach, S. Koehler, A.J. Marsaioli \& M.D.C.E. Amaral. 2004. Sexual mimicry in Mormolyca ringens (Lindl.) Schltr. (Orchidaceae:Maxillariinae). Annals of Botany 93: 755-762.

Singer, R. B., Breier, T. B., Flach, A., \& Farias-Singer, R. 2007. The pollination mechanism of Habenaria pleiophylla Hoehne \& Schlechter (Orchidaceae: Orchidinae). Functional Ecosystems and Communities, 1: $10-14$.

Swarts, N.D. \& W. Dixon. 2009. Terrestrial orchid conservation in the age of extinction. Annals of Botany 104: 543-556.

Tremblay, R. \& J.D. Ackerman. 2007. Floral color patterns in a tropical orchid: are they associated with reproductive success? Plant Species Biology 22: 95-105.

Tremblay, R. \& J.T. Otero. 2009. Orchid conservation biology: Predicting species dynamics and community interactions. In: A.M. Prigeon \& J.P. Suárez [eds.], Proceedings of the Second Scientific Conference on Andean Orchids, 97-107. Universidad Técnica Particular de Loja, Loja, Ecuador.

van der Pijl, L. \& C.H. Dodson. 1966. Orchid Flowers: their pollination and evolution. University of Miami Press, Miami, USA.

Whitten, W.M., A.M. Young \& D.L. Stern. 1993. Non-floral sources of chemicals that attract male euglossine bees. Journal of Chemical Ecology. 19:3017-3027.

Williams, N.H. 1982. The biology of orchids and euglossine bees. In: J. Arditti [ed.], Orchidbiology II, 121-169. Cornell University Press, Ithaca, New York.

Williams N.H. \& W.M. Whitten. 1983. Orchid floral fragrances and male euglossine bees. Methods and advances in the last sesquidecade. Biological Bulletin, 164: 355-395. 
